\title{
人工膝関節全置換術後に残存する屈曲拘縮の 発生因子についての検討
}

$$
\begin{array}{lllll}
\text { 高山 剛* 王 寺 享 弘* 徳 永 真 巳* } \\
\text { 吉 本 栄 治* 松 田 秀 策* 碇 }
\end{array}
$$

\section{Evaluation of Clinical Factors of Flexion Contracture in Total Knee Arthroplasty}

Go Takayama*, Toshihiro Ohdera*, Masami Tokunaga*, Eiji Yoshimoto*, Shusaku Matsuda*, and Hiroya Ikari*

人工膝関節全置換術後に残存する屈曲拘縮の発生因子について報告する。対象と方法 : 症例は 2009 年 1月から 2 月までに変形性膝関節症に対し PS 型 TKA（NexGen LPS）を行った 37 名 37 膝（男 3 名, 女 37 名）である。術後伸展角度に影響する可能性のある因子として患者背景より年齢，性別，罹病期間， BMI, 術前 JOA score を, 理学所見より術前膝最大伸展㧍よび屈曲角度を, 単純 X 線所見から北大分類 stage, 立位膝外側角抢よび脛骨後傾の術前後変化量を，術中計測値としてバランサーで計測した伸展ギャッ プからインプラント厚を減じた值，インプラント挿入後（術直後）の麻酔下最大伸展角度を設定し，検討 した。結果および考察: 術前, 術直後の伸展角度㧍よび脛骨コンポーネントの後傾が術後 4 週時の伸展角 度に影響していたが，他の因子には有意な関係がみられなかった，症例は少ないが，男性は女性に比し， 術前より屈曲拘縮が存在し，術後も残存しやすい傾向にあった。

We investigated the factors of flexion contracture in total knee arthroplasty (TKA) using a prospectively collected database of 37 knees of osteoarthritis (OA) patients for two months. We used all the same posterior stabilized type of prosthesis.

We surveyed probable factors influencing postoperative flexion contracture of patients including their age, sex, BMI, JOA scores, etc. We measured extension of the knees by means of X-ray photographs of lateral knee views at maximal extension. We further examined their OA stage, alignment, and tibial inclination. Furthermore, we measured gaps and soft tissue balances using the knee balancer intraoperatively. We investigated these results statistically.

First, we found a strong correlation between preoperative and postoperative extension of the knees. Among the possible factors, we hypothesized that the factors of sex and tibial inclination are important for postoperative knee extension.

This study suggests that maximal extension must be achieved intraoperatively in TKA for prevention against postoperative flexion contracture except genu recurvatum.

Key words : total knee arthroplasty (人工膝関節全置換術), osteoarthritis (变形性膝関節症), flexion contracture（屈曲拘縮）

\section{は じめに}

人工膝関節全置換術後の可動域に関する様々な研究 がこれまでになされており，影響を及ぼす因子の解析 を解明し，より大きい可動域を獲得するための手術手 技や機種の改良が行われてきている。これまでに術前
の可動域, 膝の内外反アライメント, 年齢, 体重, 術 前スコアなどが影響することが報告されている。しか しながらその多くは屈曲可動域を対象としたものであ り，伸展可動域に関する検討はあまりなされていない. 今回, TKA 後に残存する屈曲拘縮に着目し, その 発生因子について検討したので報告する。

* 福岡整形外科病院 Fukuoka Orthopaedic Hospital, Fukuoka, Japan 
表 1 設定した因子と術後伸展角度との関係 $+:$ 相関あり, $-:$ 相関なし

\begin{tabular}{|c|c|}
\hline • 年齢：(平均) $72.8 \pm 6.2$ 歳 & - \\
\hline - 性別：男性 3 例，女性 34 例 & +（男女 2 群間比較で有意差あり） \\
\hline ・罹病期間 : $9.0 \pm 7.0$ 年 & - \\
\hline - BMI : $26.1 \pm 2.6$ & - \\
\hline • 術前 JOA score：52.6土11.2 点 & - \\
\hline • 術前＼cjkstart膝最大伸展角度 : $-3.4 \pm 7^{\circ}$ & + \\
\hline 屈曲角度 : $123.8 \pm 17.5^{\circ}$ & - \\
\hline \multicolumn{2}{|l|}{ ・インプラント挿入後の } \\
\hline 麻酔下最大伸展角度 : $-2.8 \pm 5.3^{\circ}$ & + \\
\hline • 北大分類 stage：平均 stage3.9 & - \\
\hline • 術前, 術後 FTA, 術前/後変化量： & - \\
\hline - 術前, 術後\%MA, 術前/後変化量 : & - \\
\hline ・ 脛骨関節面後傾度 術前 : $7.5 \pm 3.8^{\circ}$ & - \\
\hline 術後 : $3.8 \pm 2.3^{\circ}$ & + \\
\hline ・伸展ギャップーインプラント厚 : $7.8 \pm 2.0 \mathrm{~mm}$ & - \\
\hline
\end{tabular}

\section{対象と方 法}

2009 年 1 月から 2 月まで（2 か月間）に変形性膝関 節症（膝 OA）に対し当院で初回 TKA を行った 37 名 37 膝を対象とした。外傷後变形や矯正骨きり後は 除外した。男性 3 例，女性 34 例，手術時年齢は 72.8 土6.2 歳であり, 術後 4 週間の経過観察を行った.

機種は全例セメント固定の NexGen LPS-Flex Fixed（Zimmer 社）を使用した。関節展開は medial parapatellar むしくは mini mid-vastus approach で 行い, independent 法で骨きり，軟部組織バランスを 整えた後，Zimmer 社製 knee balancer を用いて伸展 /屈曲位それぞれにおけるギャップ長と内外反バラン スの計測を行った。この際ギャップ長差は $2 \mathrm{~mm}$ 以 内, 内外反 $3^{\circ}$ 以内を目標とした.

術後伸展角度に影響する可能性のある因子として以 下を設定した。患者背景より年齢，性別，罹病期間， BMI, JOA score を, 理学所見より術前膝最大伸展 および屈曲角度を，単純 X 線所見より北大分類，脛 骨関節面後傾度，立位膝外側角（FTA），全下肢機能 軸（\%MA）の術前後変化量を，術中計測值として伸 展ギャップからインプラント厚（とセメント層厚：大 腿骨側, 脛骨側各 $1 \mathrm{~mm}$, 計 $2 \mathrm{~mm}$ と仮定）を引いた 值, インプラント挿入後（術直後）の麻酔下最大伸展
角度を選択し設定した。伸展角度についてはいずれむ 単純 X 線膝最大伸展側面像を撮像し測定した。

統計学的解析では各因子と術前後伸展角度の連続変 数間の関係はピアソンの相関係数検定を用い，相関係 数 $\mathrm{r}$ の絶対值 0.4 以上, $\mathrm{P}<0.05$ を有意とした。男女 間の伸展角度の差についてはマン・ホイットニ検定を 用いた。

\section{結果}

伸展可動域は術前一 $3.4 \pm 7.0$ 度，術直後一 $2.8 \pm 5.2$ 度, 術後 4 週時一 $2.5 \pm 6.6$ 度と变化し, 屈曲可動域は 術前 $123.8 \pm 17.5$ 度, 術後 $121.1 \pm 7.1$ 度と変化したが, いずれも有意ではなかった（P>0.05）。術前と術直後 $(r=0.57, \quad P<0.001)$, 術直後と術後 4 週 $(r=0.71$, $\mathrm{P}<0.001 ）$ の伸展角度はいずれも正の相関があり，同 様に術前の伸展角度が術後 4 週時の伸展角度に強く影 響していた $(r=0.74, \mathrm{P}<0.001)$.

設定因子のうち患者背景については年齢，罹病期間， BMI, 術前 JOA score はいずれも伸展角度との相関 がみられなかった（表 1 ）。男女間で伸展可動域の推 移を比較すると男性 3 例と数は少ないものの，男性は 女性に比べ術前より屈曲拘縮が存在し, 術後も残存し やすい傾向にあった(術前 $\mathrm{P}=0.109$, 術直後 $\mathrm{P}<0.001$, 術後 4 週時 $\mathrm{P}=0.051$, 表 2). 


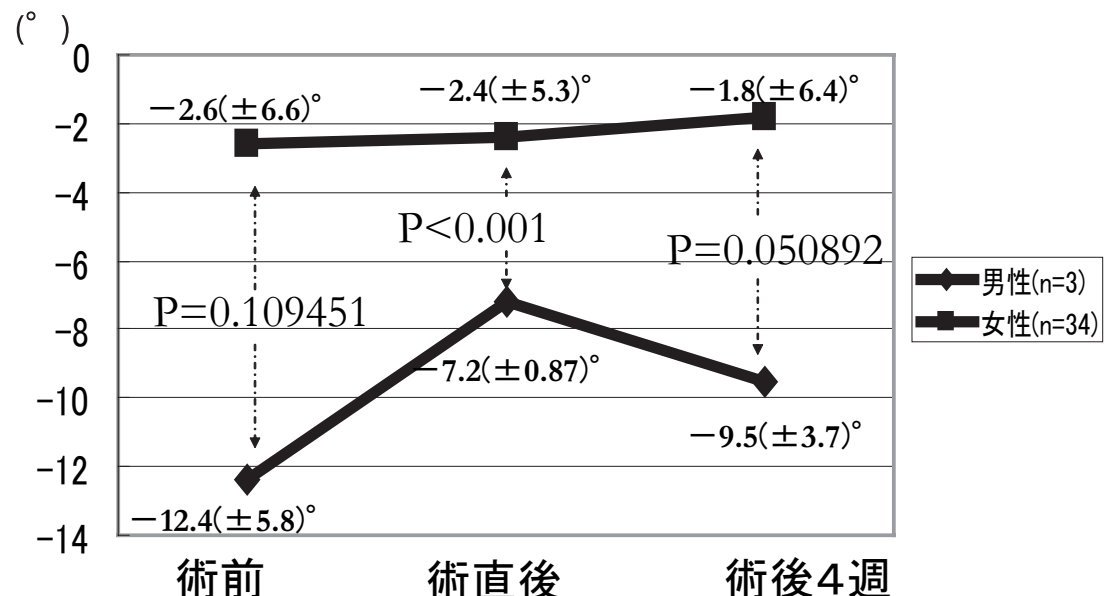

表 2 男女別の伸展可動域の変化
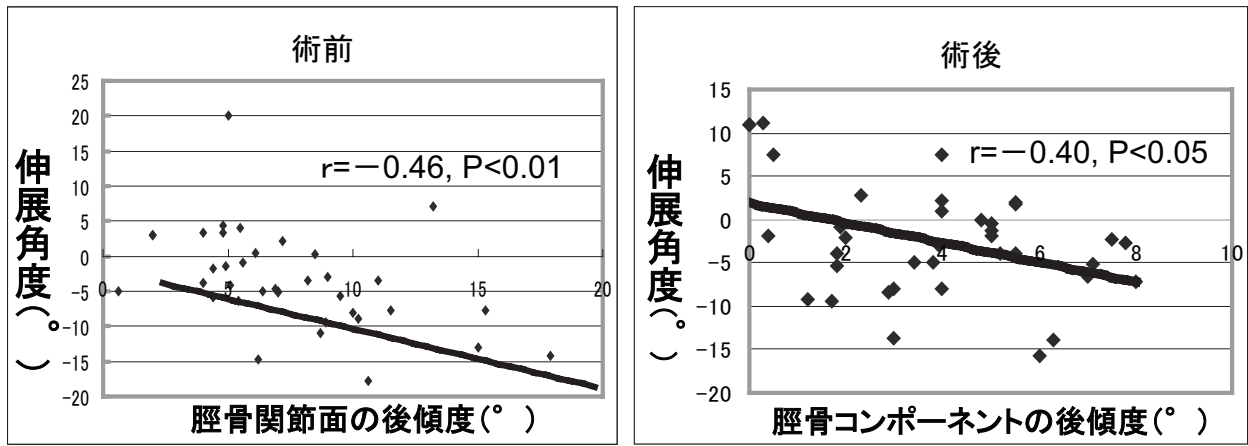

表 3 術前後の脛骨関節面後傾度と伸展角度

画像所見では，術前の OA 進行度については北大 分類 stage3 が 6 例, 4 が 27 例, 5 が 4 例であった. TKA の結果，アライメントはFTA が平均 184.6 度 から 176 度に，\%MA が平均 11.7 から 44.4 に有意に 改善していた。しかしながら OA 進行度もアライメ ント矯正角度む術後伸展角度との相関はみられなかっ た（表 1)。脛骨関節面の後傾角度は術前の平均 7.5 度が術後 3.8 度と有意に減少していたが, 減少角度と 術後伸展角度あるいは伸展改善角度との相関はみられ なかった。ただし術前後それぞれにおいて脛骨関節面 （脛骨コンポーネント設置）の後傾度が大きいほど伸 展は制限されるという負の相関がみられた（術前 $\mathrm{r}=$ $-0.46, \mathrm{P}<0.01$, 術後 $r=-0.40, \mathrm{P}<0.05$, 表 3 ).

術中所見としては内外反バランスとギャップ長はそ
れぞれ伸展時内反 $0.4 \pm 1.7$ 度, $29.1 \pm 2.2 \mathrm{~mm}$, 屈曲 時 $0 \pm 2.2$ 度, $27.9 \pm 2.4 \mathrm{~mm}$ と比較的良好なバランシ ングが為されていた。 内外反の程度と伸展角度の相関 はみられなかった。また伸展ギャップからインプラン 卜厚を引いた值は $7.8 \pm 2.0 \mathrm{~mm}$ であり，伸展角度之 の相関係数 $\mathrm{r}=0.21$ で弱い相関はみられたが有意とは いえなかった $(\mathrm{P}=0.22)$.

以上より術後の伸展角度に影響を与えた因子は性別 と脛骨コンポーネントの後方傾斜角度, 術前と術直後 の伸展角度であった。

考察

TKA 後の屈曲可動域に影響する因子としては, こ れまで河村らが術前の伸展および屈曲可動域, 膝の内 
外反変形の程度，患者の年齢・体重・術前スコア，手 術手技などを報告しているが，伸展可動域について の厳密な検討はほとんど為されてこなかった ${ }^{2)}$. TKA の術後は特に屈曲が制限されやすく，日本人にとって は和式生活の妨げにもなるため，屈曲角度を改善させ るためのリハビリテーションの取り組み，手術手技や 機種の開発が行われてきた。その一方で伸展角度につ いては，特に術後ともなればその絶対值が小さく，0 に近似され非常に定量化しづらいものであった。屈曲 角度に比べると個人間の差異む顕著化しづらいため, これまでそれほど大きく問題視されることもなく看過 されてきた可能性がある.

TKA 後の屈曲拘縮が脛骨コンポーネントおよびポ リエチレンインサートの後方ストレスを増大させ， イ ンプラントの耐久性を低下させる可能性のあることは 知られている. しかし反張膝についても機種にもよる が特にPS タイプでは前方インピンジメントによるカ ムの折損の危険性があるため, 術後は屈曲拘縮を残さ ないだけでなく，過度の反張をきたさないような工夫 が必要と思われる。そのためには術前より反張膝を把 握しておく必要があると思われる.

今回, 我々は単純 X線膝最大伸展側面像を撮像し伸 展角度を定量化したが，角度計を用いた計測による理 学所見上の角度とは隔たりがあった．屈曲拘縮膝につ いてはある程度正しく評価されていたものの，10 度 未満の反張膝は見逃されやすく, 多くが伸展 0 度とさ れていた. 今回の結果からは反張膝に対しては伸展を やや夕イトにする，脛骨骨きり時に後傾をつける（後 方の骨切除を多めに行う）などが術後過度の反張を生 じさせないための有効な予防策と思われる。

また屈曲拘縮膝への対応については Johan らが 30 度未満の拘縮であれば内外側のバランス, 骨棘切除な よ゙を行うだけの Step1 むしくは後方関節包，腓腹筋 のリリースに至るStep2 で十分とし，30 度以上であ れば $4 \mathrm{~mm}$ までの大腿骨遠位追加切除（Step3），八 ムストリング切離 (Step4) が必要と報告してい る ${ }^{13)}$. 今回の調査においては術前最大でも 18 度まで
の屈曲拘縮であり Step1（18 例）か Step2（19 例） までで問題はみられなかった。 30 度以上の屈曲拘縮 膝についてはTKA 術前に十分な対策を講じておく必 要があるだろう。

術後 4 週間と短期ではあるが，今回の検討において 術前㧍よび術直後の膝伸展角度が術後の伸展角度に影 響することが判った。このことは屈曲拘縮膝に対して は術後だけでなく術前からの可動域訓練にも意味があ ること，また術中に伸展制限を残さないことが何より 重要であることを意味している．特に屈曲拘縮を生じ やすい男性の場合は注意する必要がある。

脛骨コンポーネントの後傾については予想されるよ うな結果が得られたが, 術中の伸展ギャップと術後伸 展角度との有意な関係は見出せなかった。屈曲拘縮の 発生には複数の因子が関連していると思われるため, 今後症例数を増やした上で経過観察期間を長くし，更 なる検討が必要と思われる。

\section{結語}

1) TKA 後の屈曲拘縮の原因となる因子を調査した.

2 ）単純 X 線膝最大伸展位側面像が伸展角度の正確な 定量化に有効であった。

3 ）術前および術直後の伸展角度が術後 4 週時の伸展 角度に影響していた。

4 ）術前後それぞれにおいて脛骨関節面の後傾度が大 きいほど伸展は制限されていた。

5 ）男性は女性に比し，術前より屈曲拘縮が存在して おり，術後む残存しやすい傾向にあった。

\section{参 考 文 献}

1) Johan, B., et al.: Flexion contracture in total knee arthroplasty. Clin. Orthop., 452: 78-82, 2006.

2）河村春生：人工膝関節の術後関節可動域に影響する要 素. 日本人工関節学会誌， $36: 200-201 ， 2006$.

3) Keith, R., et al.: Total knee arthroplasty in patients with greater than 20 degrees flexion contracture. Clin. Orthop., $452: 83-87,2006$. 